\title{
FULL AUTOMATION IN ITS INFANCY: \\ THE SITUATIONIST AVANT-GARDE BOOK \\ FIN DE COPENHAGUE
}

\section{Dominique Routhier}

\section{ABSTRACT}

This article discusses Fin de Copenhague, a Situationist book experiment from 1957 by Asger Jorn and Guy Debord. By way of a contextualizing archival study with special attention to Jorn's contemporaneous book project Pour la forme, the article demonstrates that the Russian avant-garde book was a key influence if also a point of critical departure. On this reading, Fin de Copenhague marks a turn away from the unbridled technological optimism of the historical avant-garde. In its material implications and aesthetic choices, Fin de Copenhague draws attention to crucial changes in the capitalist mode of production and challenges the then nascent discourse about "full automation."

\section{KEYWORDS}

Postwar, Automation, the Situationist International, Asger Jorn, Guy Debord, Value-form theory. 
"What do you want? Better and cheaper food? Lots of new clothes? A dream home with all the latest comforts and labour-saving devices? A new car ... a motor-launch ... a light aircraft of your own ?,” asks an anonymous British ad, that, somehow, found its way into the chaotic jumble of cut-out materials making up Fin de Copenhague: a joint artistic enterprise that Asger Jorn and Guy Debord undertook in May 1957. (Fig. 1) Clippings from various newspapers, illustrated weeklies, advertisement catalogs, women's magazines, and other commercial debris from the booming postwar economy's dizzying new visual battle array form the bulk of this paint-stained, thirtysomething pages of "montage wrapped in flong." 1

In a seamless glide from the necessities in life ("better and cheaper food") to propositions about the wildest eccentricities imaginable (“a light aircraft your own”!), the British ad builds up an imaginary world that it promises to deliver in the twinkling of an eye:

Whatever you want, it's coming your way-plus greater leisure for enjoying it all. With electronics, automation and nuclear energy, we are entering on the new industrial revolution which will supply our every need, easily ... quickly ... abundantly.

"Easily, quickly, abundantly"... these three last words line up neatly with the triad of "electronics, automation and nuclear energy," a sort of holy bourgeois trinity that underwrote the postwar promise of general progress, upward social mobility, and an abundance of luxury commodities for everyone. Fin de Copenhague whirls us deliberately into the maelstrom of capitalist accumulation at a point where American-led modernization spelled out the "reordering of French culture." 2 From America to France, and from the shop floor to the glittering pages of the life-style magazines from which much of the material to Fin de Copenhague was culled, the capitalist economy seemed to be moving from a production-centered age of mechanization to a society of leisure and consumption: what Frankfurt school associate Frederick Pollock theorized as an "age of automation.”3 The British ad almost perfectly distills the collective phantasmagoria of that particular historical conjuncture: “...et voilà votrevie transformée!” (....and just like that your life is transformed!), as Debord and Jorn added, tongue-in-cheek, like a secularized French "amen" to the gospel of automation. But what kind of relation, we might ask, taking a methodological cue from T.J. Clark, does the actual, material work establish to the "dream-content" of its proper 


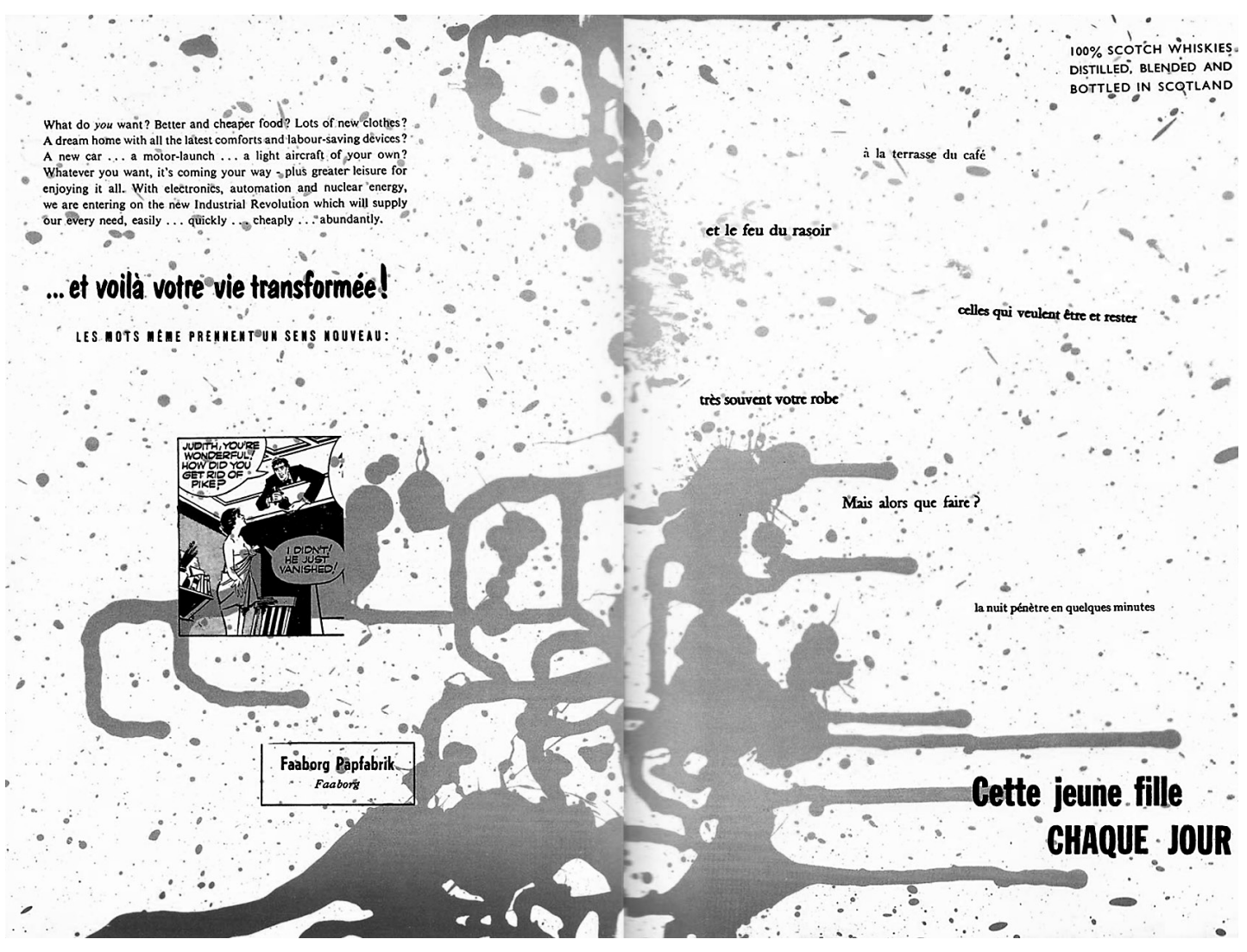

Fig. 1

Double-page spread from Fin de Copenhague, 1957 
historical moment?4 Beyond merely being "critical of publicity," is there perhaps a more profound sense in which a work like Fin de Copenhague critically interrogates the age of automation?

In this article I discuss Fin de Copenhague through a combined prism of art history and communization theory. Through a contextualizing archival study that focuses on Jorn's crucial role in the conception and making of the book-with special attention to the contemporaneous book project Pour la forme-I argue that Fin de Copenhague is in a very fundamental sense "about" the relation between artistic form and the value-form of the commodity. ${ }^{5}$ Assuming a form that sits uneasily with established art historical categories (as it is neither straightforwardly a livre illustré nor an artist's book), Fin de Copenhague continues the historical avant-garde's assault on bourgeois aesthetic categories. As I show through a reading of El Lissitzky's seminal text "The Future of the Book" (1927), Fin de Copenhague is more specifically indebted to Russian avant-garde book experiments. But it also points towards a deep historical rupture linked to the advent of postwar automation and the convergent crisis in the workers' subjectivity. Prompted by historical circumstance, then, Debord and Jorn questioned anew the bourgeois habit of seeing artistic "creation" in isolation from capitalist "production" and tried to experimentally give form to the conflicted desire to abolish work and art in one sweeping revolutionary gesture, a Situationist overturning of all values. Hence, when restored to its original context-a time when the dream of "full automation" was still in its infancy-Fin de Copenhague offers an instructive counterpoint to today's trite repetitions of the 1950s untenable promise of a world of abundance and unlimited luxury. ${ }^{6}$

\section{THE BOOK OF THE FUTURE}

When the Russian Constructivist El Lissitzky reflected upon the future of the book, he stressed the need to bring it on a par with cinema and other art forms that had managed more fully to exploit the new means of mechanical reproduction artistically. ${ }^{7}$ To Lissitzky's mind, the book was still lagging in the field of the arts, and there was an imminent need to search for a new "overall structure" that would bring the book up to date with "the recordbreaking speed of social development." ${ }^{8}$ Lissitzky wanted to bring the book-format up to date with the development in the forces of production and to let, as he proclaimed with regards to F. T. Marinetti's futurist form-experiments, "the action of a new content" be "intensified by the form." 9 
Lissitzky's programmatic text, "The Future of the Book," seems to offer a constructive point of departure for framing Fin de Copenhague art-historically while contributing, in a wider sense, to an understanding of the historically-specific concerns that propelled the Situationist movement into existence and structured their (post-)artistic responses to questions of form, content, and the "work of art" as such.

Lissitzky's argument proceeds from the idea that innovations in human language or "verbal traffic" always brought about corresponding technical innovations in "general traffic." 10 For instance, "articulated language" correlates with the "upright gait," "writing” with the "wheel," and the "Gutenberg printingpress" with "carts drawn by animal power." 11 But Lissitzky leaves a blank spot and a question mark to correlate with the era of the "automobile," and another blank to correlate with the "aeroplane," suggesting that the means of "verbal traffic" had not yet been brought up to date with their technical equivalents in the means of "general traffic." 12 To Lissitzky's mind, art was not merely one but two evolutionary steps behind.

By the 1950s, in historical confirmation of Lissitzky's farsightedness, Marinetti's semi-divine "roaring automobile" had since long been profaned by the masses. Capitalist development was seemingly also catching up with the "aeroplane," which was no longer an awe-inspiring novelty but increasingly one among several options for mass transportation which held little sway over the artistic imagination at a time when spaceexploration and sci-fi scenarios took center stage of avant-garde aesthetics. ${ }^{13}$ An accompanying feature of the spectacular spaceage was the nascent cybernetic dream of full automation with its promise of a society of unending abundance and growth. In this historical context, the prospect of "a light aircraft of your own” would symbolically underscore the beginning of a new epoch. ${ }^{14}$ When placed in a longer art-historical continuum, then, Fin de Copenhague might be read as a material approximation to fill those "blank topological spaces" in Lissitzky's schema that, according to philosopher of art Peter Osborne, were in a way "already reserved for the computer and the digital."15

\section{THE CONSTRUCTIVIST ETHOS OF MASS-PRODUCTION}

Lissitzky's retrogressive turn to the book format, at a time when cinema was celebrated as the new progressive mass medium, was not merely a question of "styling" an old medium. Rather, it was an integral step in the Constructivist masterplan to fully exploit 
the technical edifice of mass enlightenment handed over from the bourgeois mode of production (in order to use it, of course, to transgress its proper ideological constrictions). As art historian Susan Compton points out in Russian Avant-garde Books 1917-34:

Constructivism is often discussed as a "style"-especially in the field of book design-but the original protagonists saw it not as the way things might be made to look different but as a means for shaping the new society. ${ }^{16}$

Importantly, in the historical context of post-revolutionary Russia, Compton reminds us, the call for a new book and the avant-garde enthusiasm for book design was part of an answer to a situation where "the greater proportion of the population could neither read nor write." 17 Hence the need for inventing and promoting a new kind of visual communism. The production of books and the revolution in design thus followed, in the words of another expert in Russian avant-gardism, Margit Rowell, a single "overriding aim": "to generate objective methods for the rational ordering of materials so as to create practical, economical, and mass-produced objects of everyday use."18

Following the Constructivist program, Lissitzky's vision for the book of the future was to find a new form adequate to the changes in the collective reception of art. The goal, ultimately, was to help surpass the passive and spectacular mode of reception that characterized the Gutenberg book, exemplified, of course, by that (in the eyes of a devoted Marxist like Lissitzky) most pacifying of all mass-distributed books: that opiate for the people called "the Bible." ${ }^{19}$ Modernism had already taken several crucial steps towards abolishing the predominantly passive mode of reception that had been the flipside of the print revolution initiated by the Gutenberg press. The invention of the pictorial means of mechanical reproduction-notably photography and, later, cinema, as Walter Benjamin famously pointed out-helped overcome the limits of the printing press. 20 Such innovation yielded new modes of universal art-political instruction by opening up the fixed edifice of the Gutenberg press to a new visual array of broken up and combinatory forms (i.e., literary plus visual material) inspired by cinematic montage methods. 
IMAGINING COMMUNISM:

\section{THE AVANT-GARDE BOOK EXPERIMENT}

Whereas Benjamin saw a clear historical and technical (if not necessarily moral) progression from the Gutenberg press to the film, Lissitzky took a step back and focused instead on what was distinct for the book. Considered an artistic medium in its own right, Lissitzky analyzed the book's didactic and political potentials and limitations. Due to its technical inflexibility, the revolutionary reproduction of writing associated with the Gutenberg press had come up against its historical limits, Lissitzky believed. It had served not only as an instrument for mass enlightenment but also, so to speak, as an instrument for religious orthodoxy. The task for artists, according to Lissitzky, would be to take note of technological evolution and advance a new revolutionary proposition in book design on that basis:

Gutenberg's Bible was only printed with letters. But letters alone will not suffice for the handing down of today's Bible. The book finds its way to the brain through the eyes, not through the ears; light waves travel much faster and more intensely than sound waves. But humans can only speak to each other with their mouths, whereas the possibilities of the book are multi-form. ${ }^{21}$

Exploiting the new pictorial means of mechanical reproduction in the domain of the book would help educate the masses and get a message across to a new international audience. A decidedly post-religious form of mass enlightenment, the book's "multiform" options pointed in the direction of truly democratized knowledge, bound neither to the church and its clergy nor to the nation-state and its language-of-power. Hence, the book of the future would be not merely international but emphatically "antinational."22 Lissitzky's vision of literary communism thus taps into the secular development of "print-capitalism": what Benedict Anderson, in his seminal book Imagined Communities, describes as a "half-fortuitous, but explosive, interaction between a system of production and productive relations (capitalism), a technology of communications (print), and the fatality of human linguistic diversity." 23 The book, according to Anderson, is the basic form-unit of print-capitalism's historical morphology because it is "capable of virtually infinite reproduction, temporally and spatially." 24 As such, the book was an essential driver in the emergence of the secularized "imagined communities" that would 
evolve in tandem with, and ideologically bolster, the appearance of modern nation-states. ${ }^{25}$ In this perspective, Lissitzky was envisioning the book as a "message" of an imagined community to come after the era of nation-states: communism.

Flipping through Fin de Copenhague's brightly colored pages in the archive today, or, what is perhaps a more likely modality of reception in our present moment, scrolling through the dematerialized pdf version on a screen, the booklet indeed comes across as affirmative of Lissitzky's communist sentiment that the book of the future should strive to reach a mass audience by surpassing the constrictions of the Gutenberg printing press and institute a fundamentally "different relation to the world and space, to image and colour." 26 So even though Fin de Copenhague is arguably "still a single volume with a cover, a back and pages" there are several ways in which the Situationist book seems to answer Lissitzky's call for a new kind of book. ${ }^{27}$

For one, the pages are deliberately unpaginated and the book seems designed to be "read" in all directions. And secondly, while Fin de Copenhague apparently remains partly tied to the alphabetwhich Lissitzky designated as "national" because built from sound-imitation-it is decidedly "international" in both scope and ambition. ${ }^{28}$ One might even say that Fin de Copenhague lives up to the most important criteria that Lissitzky stipulated for the book of the future, namely that it should be not only inter-national but essentially "non-national," in the sense that one "needs the least education to understand it." 29

In any case, the Constructivist ambition to produce a work of art that was truly on a par with the real and imagined state of the "general traffic" at a given stage of capitalist development of the productive forces seems to find a crystal clear echo in a letter of instructions that Jorn sent to the printers of Fin de Copenhague, Otto Permild and Bjørn Rosengreen, in the context of making its “sequel," Mémoires:

I do not know if you realize how close we are coming to an entirely new understanding of the book. The two books [Fin de Copenhague and Mémoires] we are making here together will become focal points for this renewal. Books printed in offset are not an entirely new phenomenon, but up until now they have been made to imitate Gutenbergian books. ${ }^{30}$

Jorn stages the Situationist book experiments as surpassing the Gutenberg book and pointing towards a form more adequate 

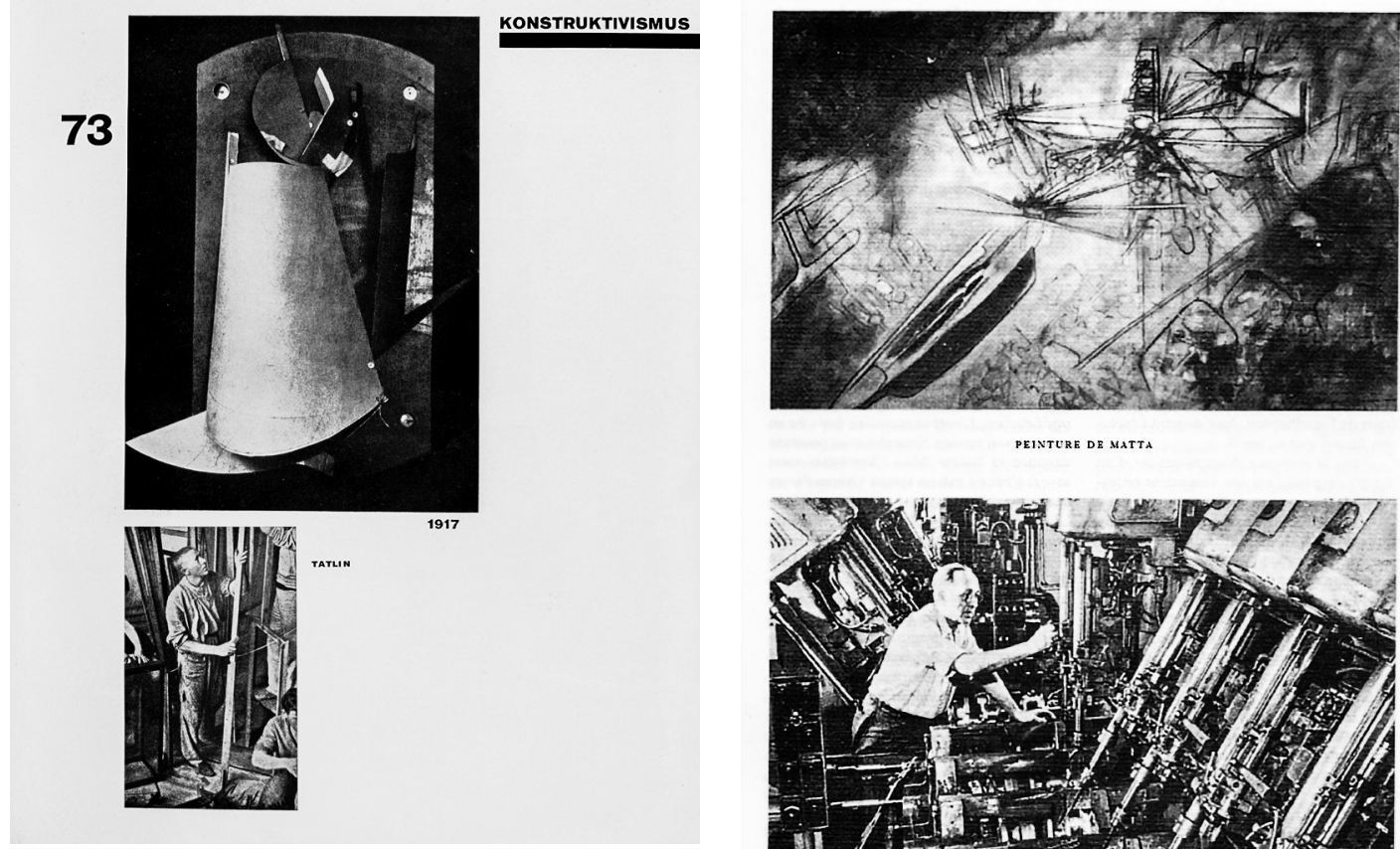

PEINTURE DE MATTA

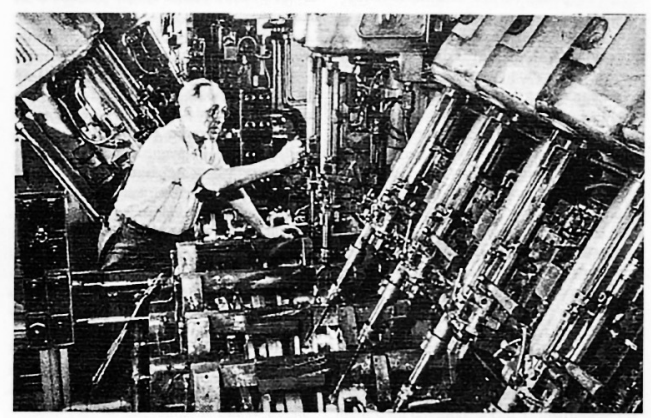

OUVRIER DANS UNE USINE AUTOMATISEE

Fig. 2

Page from the book Kunst-ism, 1914-1924, 1925.

Fig. 3

Page from the book Pour la forme, 1958.

Fig. 4

Cover of the French illustrated science magazine Atomes, October 1956.

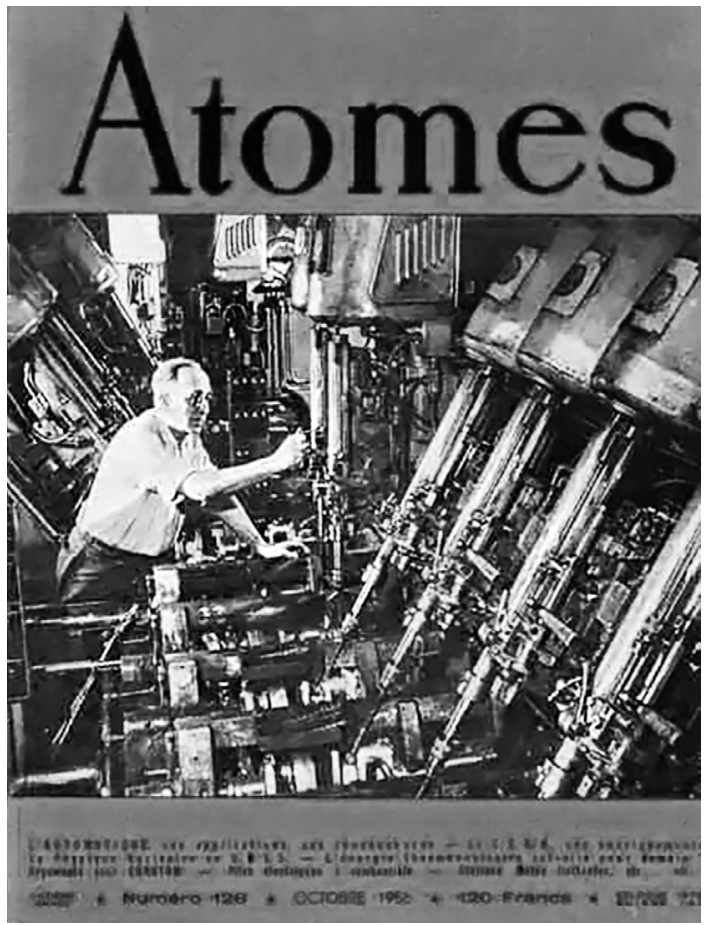


to what he describes, further on in the same letter, as the "new freedom" offered by offset printing technology. ${ }^{31}$ In that, Jorn projects Fin de Copenhague and Mémoires onto the empty blank field in Lissitzky's schema of technical evolution. If one can detect a Constructivist impulse, it was certainly not thanks to Debord, who in 1957 admitted in personal correspondence that he was practically unaware of the Russian constructivists and had up until that point somewhat naively assimilated everything of the kind to Malevich's famous black square. ${ }^{32}$ More likely, then, the Constructivist gist of Fin de Copenhague was due to Jorn's influence.

Jorn had been exposed to Russian avant-gardism through his political and artistic formation in Denmark before and during the Second World War. His massive book and printproduction as an artist was, as one scholar notes, "deliberately targeted at different approaches to avant-garde aesthetics" and betrays his longstanding interest in Russian avant-garde bookcraft. ${ }^{33}$ More specifically, the revolutionary ideas in the domain of the book were likely passed on to Jorn by "Denmark's first avant-gardist,” Rudolph Broby-Johansen, who was a source of profound inspiration for Jorn in his life-long engagements with the traditions and innovations of book craft. ${ }^{34}$

Jorn would render homage to Broby-Johansen on several occasions, for instance, in a personal letter from 1963 that applauded Broby for being nothing short of "the most significant and revolutionary book artist" of a generation, and "not just in Denmark, but in the entire world." 35 In an article with the alluring title "Art and Orders: On Treason, the Mass Action of Reproduction and the Great Artistic Mass Effect,” from 1964, Jorn would publicly confirm Broby-Johansen's crucial importance, stating that the "great success" of Fin de Copenhague was founded entirely "on the basis of Broby-Johansen's book craft" which he had simply "enlarged to American size."36 As a Communist and experimental artist and poet, Broby-Johansen was engaged very early on in an international exchange of perspectives with likeminded revolutionary artists. Among those that made the most lasting imprint on Broby-Johansen's conception of book-craft and typography, as he recalls in his book Sort og Rødt: 64 Grafiske Glimt, was the Russian Constructivists and, most notably among them, Lissitzky. ${ }^{37}$

\section{PATTERNS OF RECURRENCE}

But even if there seem to be striking similarities in scope and 
ambition between the Russian avant-garde book and its postwar reprisal, it is also important to take heed of the historical period that lies in between: a straightforward claim that Fin de Copenhague is heir to the Russian avant-garde can only be maintained with important reservations. Broadly speaking, the project of the historical avant-garde-its political programs, its material techniques, and its aesthetic procedures-was passed on to its postwar successors in an almost fully disintegrated state. The postwar generation of avant-garde artists were, so to speak, delivered over to an impossible project of reassembling the fragments of an always-already distorted historical unity. ${ }^{38}$

As convincingly argued by Jaleh Mansoor, any act of repetition of avant-garde tropes and strategies would necessarily have been mediated by the cultural dynamics of capitalism's "systemic cycles of accumulation" that lie between the experience of the historical avant-garde and its postwar successors. ${ }^{39}$ If Fin de Copenhague was at least a partial reprise of the Constructivist mandate in art, how did Jorn and Debord mark out their difference in repetition? In this regard, it is instructive to consider the role of "work" or "labor" in Situationist discourse around the time when Fin de Copenhague was conceived. Compare, for instance, an imagespread from Jorn's book Pour la forme (1958)-which was in the making by the time Jorn and Debord made Fin de Copenhaguewith a quite similar spread from Lissitzky's and Hans Arp's joint book from 1925, the famous Kunst-ism, 1914-1924: (Fig. 2/3)

The similarities are striking if, perhaps, fortuitous. But it is the difference to which I attach historical meaning. Whether or not Jorn intended it, this particular image-spread contrasts with Kunst-ism on several important points. ${ }^{40}$ On a first impression, Jorn's image-spread seems to suggest a rather schematic labor theory of art. A simple visual analogy is marshalled to prove that what is going on in the depth of the factory comes across on the surface of modern artistic expression. But this is not the point, I would argue. Whereas Tatlin's 1917 "counter-relief" is accompanied by a picture of the artist-as-producer, Jorn presents the "painting by [Roberto] Matta" alongside an anonymous "worker in an automated factory," as the caption states. In contrast with the image of Tatlin, dressed in work garments and surrounded by co-workers in the workshop, the image of the "worker" in the automated factory represents an altogether different if not directly inverted situation (as the positioning of the hands of the two men would indeed suggest). Notice, also, how the apparently middle-aged (white) man wearing a white-collar 
shirt and glasses does not resemble an industrial worker so much as an "overlooker" or manager that has only temporarily stepped into the self-acting "automatic" machinery in order, perhaps, to tend to some minor technical detail. In Kunst-ism the artist-asproducer is the central figure, it is art not work that is profaned. It is artistic subjectivity, which is called into question: not the subjectivity of the proletarian worker as such. By contrast, in Pour la forme, the human presence appears as an anomaly of sorts. What the comparison to Lissitzky and Arp brings out, then, is the fact that the "worker" in question is by no means an unmediated representation of a situation from everyday life (in casu labor). Rather, like the "ready-made" elements from which Fin de Copenhague is composed, the image of the (white, male) machine-tender is part of the existing visual economy of the age of automation. Perhaps he is even something like the other face of the always smiling housewives in the 1950s commercials for gendered and ultimately also racialized consumer products like laundry soap and labor saving "gimmicks" of all sorts: "a dream home with all the latest comforts and labour-saving devices?," as Fin de Copenhague cunningly asks. ${ }^{41}$

What the visual comparison brings out, then, is that the figure of the "worker" (and, by implication, the representation of work) no longer functions according to the same coordinates as before. Why not? There are (at least) two interrelated aspects of this shift. Firstly, during the 1950s, the French sociology of work, with figures like Alain Touraine, gained prominence with a theory about an "ABC" of industrial evolution: an imagined process of three stages (stage $A$, stage $B$, stage $C$ ) where the deskilled working class would supposedly be transformed into a segment of upskilled managers mindfully tending the new fully automated factories that were mushrooming in France at this point. In Tourain's projected "post-industrial" society, laborstrife, wild cat strikes, and riots would be left on the dustbin of history together with the faded memory of Tatlin's project for the Monument to the Third International (which is, of course, what Tatlin is constructing on the photo).

Secondly, and related to this first point, the figure of the worker in the "age of automation" was no longer considered a "gravedigger of capitalism" but had become an integral part of the visual economy of what Debord would refer to as the "spectacle": defined as "capital that has accumulated to such a degree that it becomes image." 42 And as it appears, Jorn did indeed snatch this particular photograph from the "common stream" of images that 
according to Debord and the Situationists constituted a "pseudoworld apart.”43 (Fig. 4)

Taking this context of popularization or vulgarisation into consideration-with the popular science journal, Atomes, being the French 1950s equivalent of Science Illustrated and thus a major site of spectacular investment-it becomes clear that Jorn's visual proposition in Pour la forme is not founded on any schematic labor theory of art or a crude Marxist "reflection theory." It is rather something like a historically specific meditation on work and its modes of representation. To sum up the argument so far we can say that Jorn's gesture of détournement attests to a situation in which labor had finally lost its spell for the avantgarde and was no longer posited as "the source of all wealth and culture," just as the manual worker was no longer unproblematically posited as the role model of the revolution. The loss of faith in work and in the "worker identity" maps onto the waning of what Roland Simon calls "programmatism," a theory and practice oriented towards the horizon of the workers' class-identity and its countless programs. 44 With the onset of postwar automation, and the restructuring of the class relations that it entailed, the affirmative vision of work that had also structured the avantgarde experience historically was entering into the terminal phase of a protracted crisis-symptomatized in part by Touraine's post-industrial conundrum to which Fin de Copenhague and other early Situationist works responded.

\section{FHEIDEOLOGYOF "FULL AUTOMATION"}

As a proxy for similar concerns in Fin de Copenhague, it is worth noting a terminological detail in the aforementioned letter to the printers. In this letter, Jorn specified that the "intention" was that the work "should be finished without us having anything to do with it-so total industrialization.” 45 The original Danish term in the letter to the printers (situated in the Jorn archive in Silkeborg) is "komplet industrialisation" (a term which itself sounds like an Anglicism). Clearly, given the context, the term "industrialisation" functions as a generic stand-in for "automation," which, at this point had only recently gained currency in languages such as English and French but had not yet been fully established in Danish. ${ }^{46}$ For reasons immanent to the problematic, an alternative translation of "komplet industrialisation" (and one resonant with contemporary political theory) would be "full automation." And automation was, in fact, a topic of great concern to the Situationists at this point. In a letter to Jorn dated September 1, 1957, Debord writes: 
After the Fin de Copenhague experiment, I gathered a great number of elements to construct the story I've been telling you about [a reference to Mémoires which appeared in 1959]. I'll ask you for some colored lines complex enough that they can form the "load-bearing structure," as they say in architecture. If Permild is ready for a much greater shock, it will work out well. I've also gathered some citations for an article on the prospects held out by automation, an article that we should, I think, write together. 47

This letter to Jorn, written in the aftermath of the founding conference of the Situationist International (SI) in July 1957 in Cosio d'Arroscia, Italy, lists some of the projects that Debord hoped would help to create "a new legend" about their newly founded organization. ${ }^{48}$ Debord's letter to Jorn, which is included in the author's published correspondence, provides an entry point into the much understudied topic of automation in the SI. If one consults the original letter (currently kept in the Debord archive in Paris), one notices a minor but telling detail that looks like this:

I am also assembling some eitations ideologieal elements citations for an article on the perspectives of automation, which, I believe, we should write together. 49

Crossing out words as he wrote, Debord was apparently at odds with himself whether he should use the neutral word "citations" or the more straightforward "ideological elements" to describe the text fragments and cut-outs that he was in the process of gathering. It is clear, then, that the proposed article was intended as a critical response to the ideology of automation-as encapsulated in the British ad's hyperbolic discourse about a capitalist society of abundance-and a development of the "perspectives" foreclosed by such ideology.

In addition to this, one finds among the preparatory drafts for Pour la forme (held in the Asger Jorn archive at Museum Jorn, Denmark) a series of chaotic, and hitherto overlooked, handwritten manuscript pages on the topic of automation that apparently predate Debord's letter. (Fig. 5) As it appears, Jorn had already-either shortly prior to or more directly in conjunction with the making of Fin de Copenhague-engaged intensely with the question of automation. First jotted down somewhere around March 1957, in response to a lecture by the Argentinian designer Thomas Maldonado at the ICA London, Jorn's two major drafts 


\section{CONTRE L'AUTOMATION DE L'HOMME.}

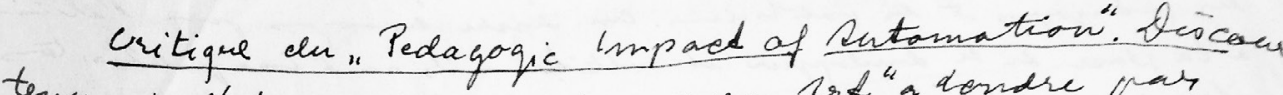

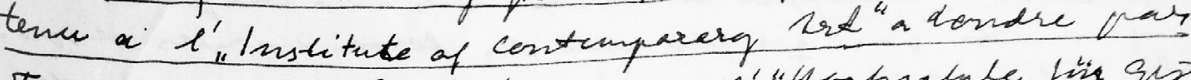

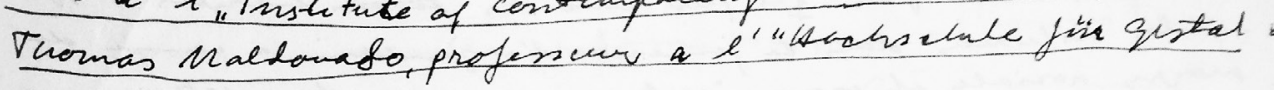
ting" Ulm, Rlarage.

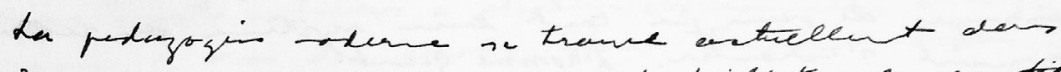

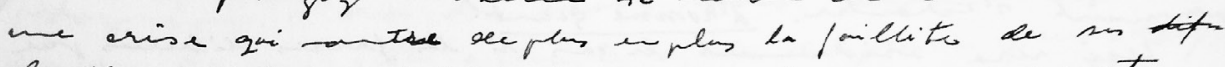

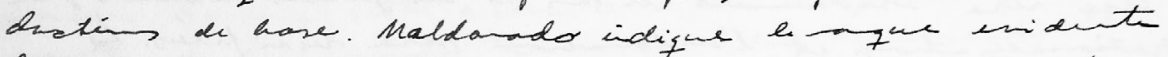

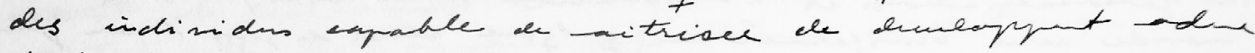

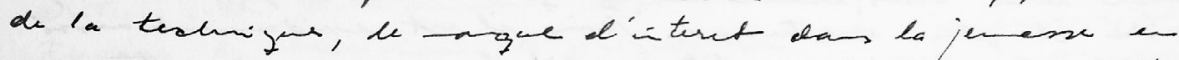

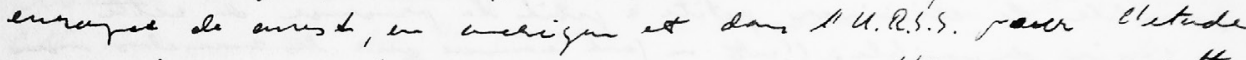

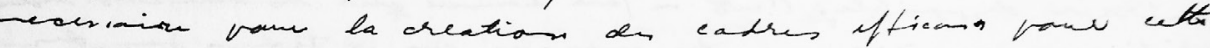

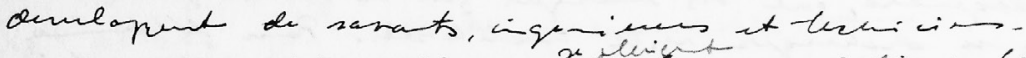

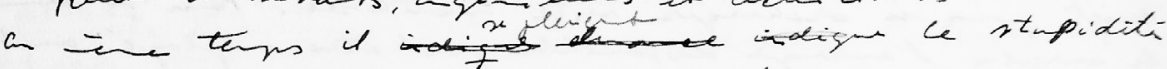

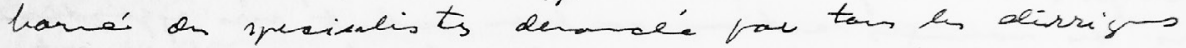

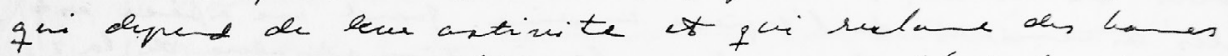

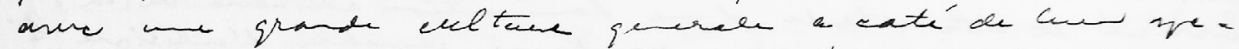

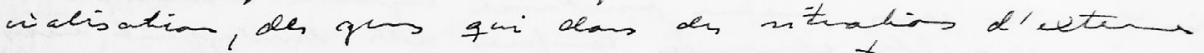

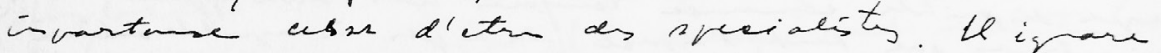

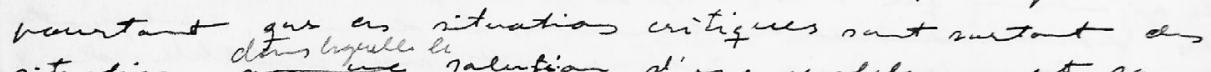

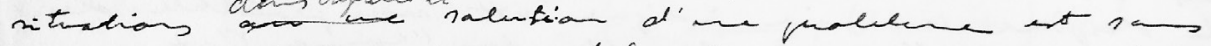

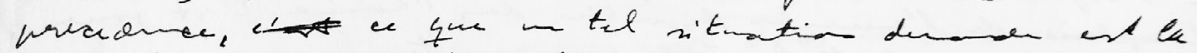

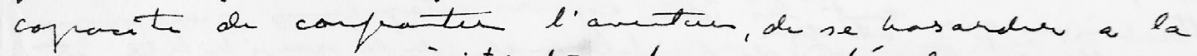

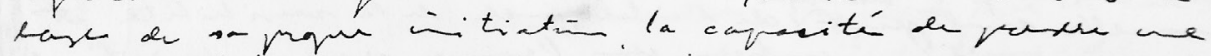

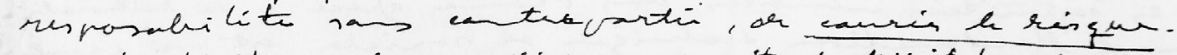
Le filit na hecen diceur an citank whitubead: educa

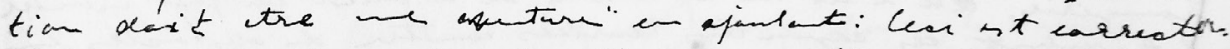

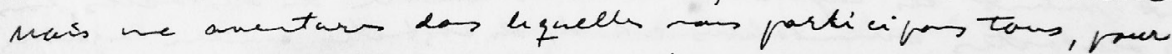

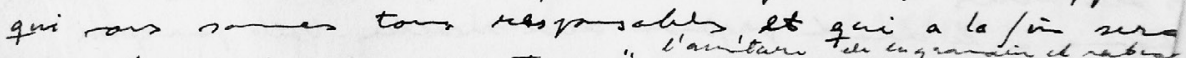

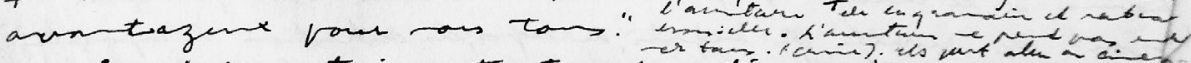

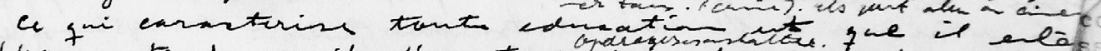

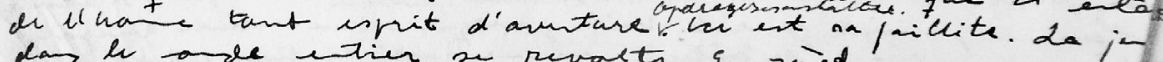

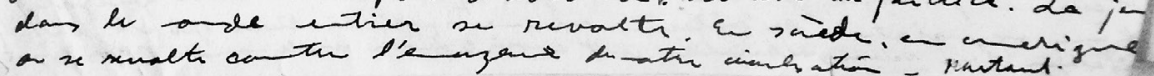
a

Fig. 5

Manuscript by Asger Jorn, ca. 1956, Jorn Archive, Museum Jorn, Silkeborg 
(comprising around five hand-written pages each) carry allusive titles such as "L'âge robot. Sur le rôle de l'incertitude pour le développement de l'intelligence. Contre l'automation de l'homme," and, more simply, "Contre l'automation de l'homme."

These texts, though following their own anarchic Jornian development of thought and argument, clearly prefigure the more concise "Les Situationnistes et l'automation," which was first published, under the sole signature of Jorn, in the collection of essays that made up the book Pour la forme (which Debord helped revise and edit, like most other French texts by Jorn). ${ }^{50}$ Debord, quite apparently, considered the article a cornerstone in emergent Situationist theory, as it was included in the first issue of the SI's eponymous journal (1958) and republished on several occasions during the existence of the SI, for instance in the little-remarked bulletin Cahier pour un paysage à inventer (Montreal, 1960) that was conceived as a Situationist outpost in North America. ${ }^{51}$

In this crucial text, Jorn engages with the concept and reality of automation primarily by way of adversary or "ideological" viewpoints. One of the principal antagonists was the traditionalist catholic, right-wing writer Louis Salleron whose book L'automation had recently appeared in the popular Que sais-je series. The series-with its unique combination of vulgarization of complex matters (often philosophical, scientific or technical in nature) and a flair for singling out topics that would resonate across the public imaginary-had instituted the livres de poches sales revolution in France. ${ }^{52}$ Salleron's L'automation opens with the following précis:

In 1947 a new concept destined to a singular fortune was born: automation. Two men have claimed paternity: D.S. Harder, executive vice-president of Ford, Cleveland, and, John Diebold, professor at Harvard University [...] What is automation? Hundreds of definitions exist already. We could say, in the simplest manner, that automation is the ensemble of automatic procedures that replace the labor of man..$^{53}$

As Salleron admits, replacing the labor of man has always been an incentive for capitalism even in the age of simple mechanization. One of the great points of discussion in relation to the topic of automation, a topic that, according to Salleron, already "counts articles in the thousands," was to define the term vis-à-vis the term mechanization. ${ }^{54}$ Against this backdrop 
of nascent automation-theorizing, Jorn intervened not with an argument about what constitutes automation technically speaking (cybernetic feedback mechanisms would typically be invoked in such argument) but rather to underscore a primary social fact about mechanical reproduction as such. According to Jorn, any proposed solution to simply "socialize" production on the basis of existing automation techniques would be to continue the capitalist devaluation and neutralization of the singularity and uniqueness of human existence:

The goal of socialism is abundance: the greatest number of goods for the greatest number of people, which statistically implies reducing the unexpected to the level of the improbable. Increasing the number of goods reduces the value of each. This devaluation of all human goods to a level of "total neutrality" will be the inevitable consequence of a purely scientific development of socialism. It is unfortunate that many intellectuals fail to get beyond the idea of mechanical reproduction, and are instead contributing toward the adaptation of humanity to this bland and symmetrified future. 55

Pointing to "abundance" as the highest goal of socialism, and showing that the adherence to the capitalist course of technical progress contradicts that same goal, Jorn is producing an argument against socializing production without revolutionizing at the same time the very foundations of this kind of production, to wit a capitalist production oriented towards the extraction of surplus value and the realizations of profits. The much fabled "take over" of the means of production would merely imply a formal change of ownership where workers would then be partaking in the exploitation of all by all to the detriment of any kind of free individual expression.

Hence, to Jorn, traditional Marxist theory had failed to think the question of technology through. The problem of automation, to a bourgeois mind as well as to the socialist mind, consequentially appeared as a problem of how to plan for a future that was conceived as an extension of the present, rather than a future oriented towards what technical progress had made imaginable and hence also possible. Automation expends with labor and frees up time for leisure, everyone agreed on this point. But as Jorn sarcastically notes: 
the new leisure time appears as an empty space that presentday society can imagine filling only by multiplying the pseudo play of pathetic hobbies. But this leisure time is also the basis on which could be built the most magnificent cultural construction that has ever been imagined. This goal is obviously outside the concerns of the partisans of automation. It is in fact antagonistic to the direct tendency of automation [...] Automation can develop rapidly only once it has established as a goal a perspective contrary to its own establishment, and only when it is known how to realize such a general perspective in the process of the development of automation. 56

Considered in the light of Jorn's theory of art, the Situationist project comes across as a necessary "artistic" corrective to Marxist thought. The artistic imagination, Jorn believed, was a precondition for the eventual overthrow of capitalist relations of production. A kind of ontological inversion thus takes place in Jorn's theory where "art," as Graham Birtwistle argued in his seminal examination of Jorn's theoretical oeuvre, is "placed in the basis and not in the superstructure." 57 Throughout his theoretical oeuvre, Jorn insists on the necessity of a Nietzschean (or Bataillan) overturning of values as a precondition for a successful revolution that would not merely "complete" the bourgeois revolution. In fact, Jorn's critique reads as an early approximation to a valuecritical method insofar as he singles out the historical specificity of the value-form of the commodity. Jorn's critique essentially aims to show that it is, in fact, entirely

possible to accept Marx's analysis and critique of the capitalist form of value, the commodity, without thereby accepting the identification of this form with value as such [la valeur en soi]. That is to say that it is possible to accept the scientific side of Das Kapital without thereby automatically accepting the political conclusions that have been drawn from it. 58

Having made an impoverished economic conception of "wealth" the basis of their program, the workers' movement, Jorn charges, has imagined communism as a simple "socialization" of an impoverished wealth without inquiring critically into the historical specificity, the social form, that this wealth acquires under capitalist relations of production. 59 This is why automation, which is a tendency in capitalism pushed to its most extreme and inhuman consequence (making labor itself superfluous to 

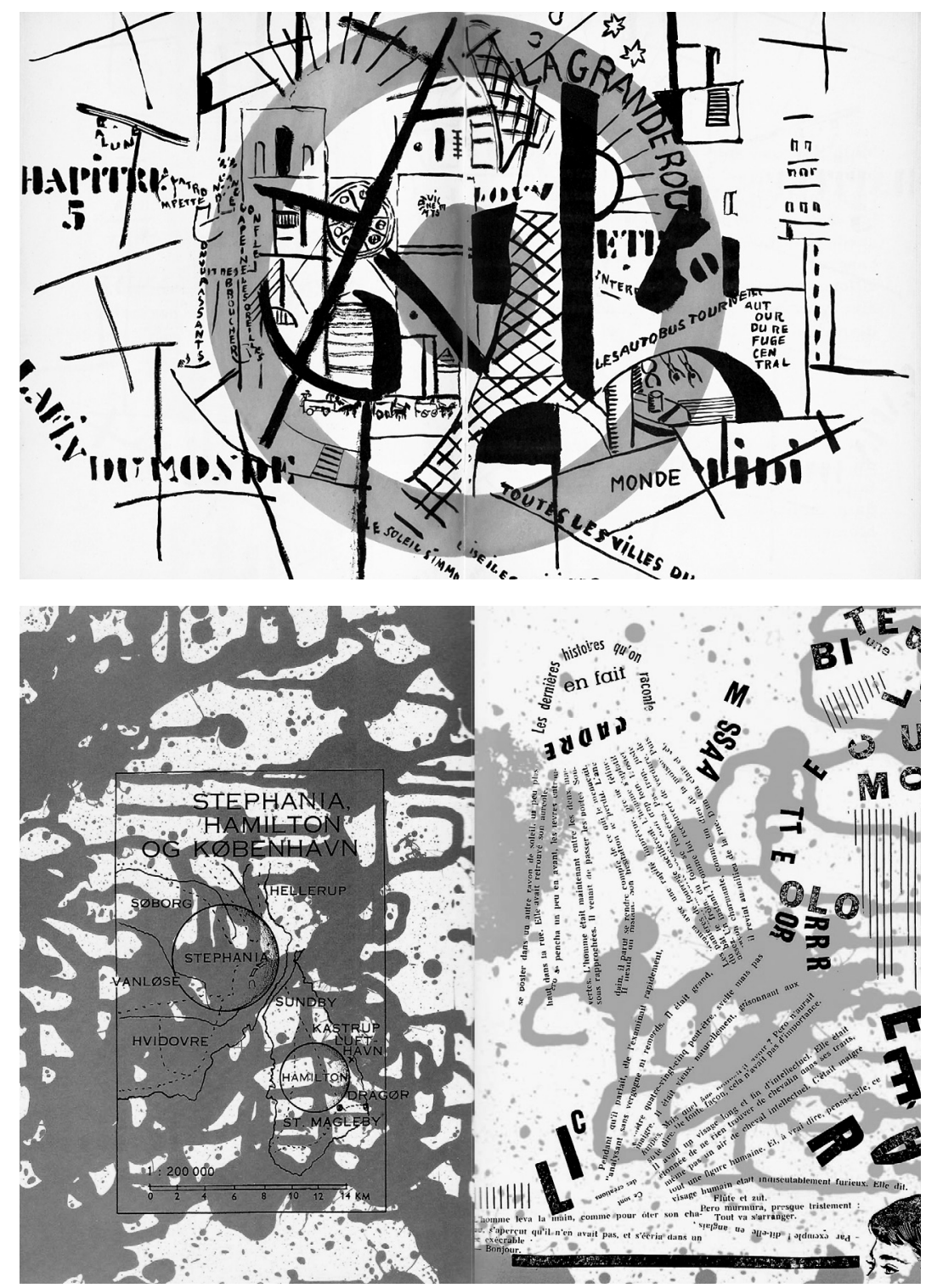

Fig. 6

Spread from La Fin du Monde, 1919.

Fig. 7

Spread from Fin de Copenhague, 1957. 
production), will never in and by itself accomplish communism as something qualitatively different from capitalism. What is required, according to Jorn, is an inversion of the principles upon which automation is founded. The basis of communism, if we take Jorn's argument to its ultimate conclusion, will not be "work," with "abstract labor" as the supreme social value, but the creation of $a$ different kind of surplus irreducible to the value-form of the commodity. ${ }^{60}$ But how does the actual material artwork, the Situationist avant-garde book Fin de Copenhague, perform its secret affinity with the value-form of the commodity?

\section{THE PERFORMATIVE DIMENSION}

It is sometimes said that one should not judge a book by its cover. But, to take a cue from Thomas Hvid Kromann's excellent analysis, we can note that Fin de Copenhague literally wears its heart on its sleeve. In this case, of course, its sleeve is made of "flong": the anonymous "readymade" material that Jorn and Debord chose to wrap their publicity-montages in. "Flong," as Kromann explains, is a residual "waste-product from the production of newspapers by stereography." 61 The choice of material thus

combines a unique element of the mass-produced with a massproduced element of the unique: the flong was fabricated as part of an industrial process, but represented a one-off. At the same time, this unique part was a waste product. In this paradoxical process, an auratic artefact was re-established, an artwork in the format of the book. 62

But not so soon is an auratic quality reestablished on the level of form before it is called into question again on the level of performativity: "Fin de Copenhague," as Kromann notes, "was priced as a book and not as an artwork, despite its unique cover, and despite the fact that each copy was numbered and signed."63 In addition to the 200 numbered and signed copies of the first edition of the book, one must add an "unknown quantity" that were hors de commerce or in some other way out of the loop from the established channels of art-world distribution. ${ }^{64}$ How many additional copies were printed remains on the level of pure speculation. But with regards to the sequel to Fin de Copenhague, the Mémoires, Jorn wrote to the printers that:

We need a thousand copies and you can print as many as you would like in addition to that. Even if you print ten thousand. 
Of our one thousand copies we want 250 bound and numbered.

If you want to raise this number, you can.65

One wonders, then, if it is not fair to assume that the same cavalier attitude to art-world conventions would have equally applied to Fin de Copenhague. The point here is that the nascent Situationist art political strategy apparently consisted in subverting the category of the "work of art" from within-by simultaneously appealing to the "structures of meaning, expectation and reception" of the art world and undermining these conventions in one and the same "performative" act.66

On this reading, Fin de Copenhague is a performative gesture that brought the Constructivist ethos of mass production to bear on the postwar moment's resurfacing of Modernist art practices and intended the former's destabilization by its own proper means. What is significant is the fact that Fin de Copenhague brings the "art world" and the world of the commodity (as a diagram for labor, time, and value) onto a single plane of evaluation: that of the book. The dizzying whirls of paint and the elements of collage that make up the "aesthetic content" of the book seem not only to nod to American Ab Ex painting or Pop Art, or to allude to bodily fluids or some such thing. ${ }^{67}$ More profoundly, when placed in conjunction with the formal contradictions spelled out above with reference to the avant-garde book tradition, Fin de Copenhague seems to be forcing a point about the spiraling logic of capital accumulation and the aesthetic disorientation that ensues.

Seen from this point of view, the book closely traces a path that led from Gutenberg via Lissitzky to Marshall McLuhan, for whom, famously, the front page of any given newspaper, as stated in his 1951 classic The MechanicalBride, refracted in miniature "the image of a world society." 68 McLuhan famously celebrated the fact that modern science and technology had led to a conception of the entire "planet as a single city."69 Fin de Copenhague, by contrast, seems more like an ambiguously positioned coordinate on the imploding world map; a place, paradoxically, both somewhere very specific and nowhere at all. The "end" of Copenhagen, then, is also, in a sense, the end of the world. Or in French: La Fin du Monde. Which was, coincidentally, also the title of an experimental book from 1919 by Jorn's former teacher, the French painter Fernand Léger, who under the influence of Lissitzky and Russian Constructivism became one of the European pioneers of book design. (Fig. 6/7)

More than simply referring to a specific geographical location, as marked out by the cartographic renderings of Denmark 
scattered over the book's pages, "Copenhague," then, also becomes an allegory for the "world" considered under the aspect of an anonymous global process of capital accumulation. In this, Fin de Copenhague prefigures a concern with the problem of "representing" capital. ${ }^{70}$ If capitalism "creates a world after its own image," to sample the famous phrase from the Communist Manifesto, that image was clearly the object of critique in Fin de Copenhague-and in the Situationist International more broadly. The joint artistic enterprises that Jorn and Debord undertook in the late 1950s were attempts to rearrange the ideological materials of the age of automation in order to show that another possible world, beyond mechanical reproduction, is hidden in plain sight. 
1 For the most meticulous archival study of this book, see Thomas Hvid Kromann, “Montages Wrapped in Flong: A Material-Archaeological Investigation of Asger Jorn and Guy Debord's Fin de Copenhague," Situationniste Blog - A Situationist Book Collector's Blog (blog). Accessed on January 19, 2016, https://situationnisteblog.files. wordpress.com/2016/01/kromann_montages_englishsummary-1.pdf; A more developed version is available in Danish, see "Montager svøbt i matricepap. En materialearkæologisk undersøgelse af Asger Jorn og Guy Debords Fin de Copenhague," Fund og forskning 54 (2015): 587-625.

2 Kristin Ross, Fast Cars, Clean Bodies: Decolonization and the Reordering of French Culture (Cambridge, Mass.: MIT Press, 1996).

3 Frederick Pollock, Automation: A Study of Its Economic and Social Consequences, trans. W.O. Henderson and W.H. Chaloner (New York: Frederick A. Praeger,1957).

4 T.J. Clark, "The Conditions of Artistic Creation," Times Literary Supplement, May 24, 1974, 561-62.

5 For an excellent inquiry into the question of art's relation to the value-form, see Daniel Spaulding, "Value-Form and Avant-Garde," Mute Magazine, March 2014, http://www.metamute.org/editorial/articles/ value-form-and-avant-garde.

6 A representative example of recent postcapitalist discourse that embraces the idea of "full automation" is: Nick Srnicek and Alex Williams, Inventing the Future: Postcapitalism and a World without Work, Revised and updated edition (London: Verso, 2016); For an insightful discussion and critique of the postcapitalist imaginary, see: Dave Beech, Art and Postcapitalism: Aesthetic Labour, Automation and Value Production (London: Pluto Press, 2019).

7 El Lissitzky, “Unser Buch (U.D.S.S.R.)," GutenbergJahrbuch 2 (1927), trans. as "The Future of the Book," New Left Review, no. 41 (February 1967): 39-44.

8 El Lissitzky, "The Future of the Book," 43.

9 Ibid., 41.

10 Ibid., 40.

11 Ibid., 40.

12 Another translation for the term "traffic," one more resonant with contemporary concerns, would be "communication," cf. EI Lissitzky and Sophie LissitzkyKüppers, El Lissitzky, Life, Letters, Texts, trans. Helene Aldwinckle and Whittall (London: Thames and Hudson, 1980).

13 See Stephen Petersen, Space-Age Aesthetics: Lucio Fontana, Yves Klein, and the Postwar European Avant-Garde (University Park, Pa.: Pennsylvania State University Press, 2009).

14 "An epoch that has variously been called the Jet Age, the Detergent Decade, or the Second Industrial Revolution." Banham added that whichever label one might prefer it seemed certain that "with the current revolution in control mechanisms [...] we have already entered the Second Machine Age [...] and can look back at the First [...] as a period of the past.": Reyner Banham, Theory and Design in the First Machine Age (1960; repr., New York: Praeger Publishers, 1970), 9.
15 Peter Osborne, The Postconceptual Condition: Critical Essays (Brooklyn: Verso, 2018).

16 Susan Compton, Russian Avant-Garde Books 1917-34 (London: The British Library, 1992), 130.

17 Ibid., 10.

18 Margit Rowell, "Constructivist Book Design: Shaping the Proletarian Conscience," in The Russian Avant-Garde Book: 1910-1934, ed. Deborah Wye and Margit Rowell (New York. NY: Museum of Modern Art, 2003), 51.

19 El Lissitzky, "The Future of the Book," 41-43.

20 Walter Benjamin, "The Work of Art in the Age of Mechanical Reproduction," in Illuminations, ed. Hannah Arendt, trans. Harry Zohn (1969; repr., New York: Schocken Books, 1986), 217-52.

21 El Lissitzky, "The Future of the Book," 42.

22 Ibid., 40.

23 Benedict Anderson, Imagined Communities: Reflections on the Origin and Spread of Nationalism (London New York: Verso, 2016), 42-43.

24 Ibid., 44.

25 Ibid., 44.

26 El Lissitzky, "The Future of the Book," 43.

27 Ibid., 43.

28 Lissitzky contrasts the national character of the "alphabetic book" with the "hieroglyphic book" that is potentially international by virtue of the fact that "if a Russian, a German or an American fixes the sign (picture) of a concept in his mind he can read Chinese or Egyptian (soundlessly), without learning the language, for language and writing are always one creation as far as he is concerned." El Lissitzky, "The Future of the Book," 40.

29 Ibid., 40.

30 Letter from Jorn to Otto Permild and Bjørn Rosengreen, February 14, 1958. Jorn Archive, Museum Jorn in Silkeborg, Denmark: Asger Jorn, “Dear Friends," trans. Niels Henriksen, October 141 (2012): 72.

31 Ibid., 72.

32 Guy Debord, Correspondance. Vol. 1: Juin 1957 - août 1960 (Paris: Librairie Athème Fayard, 1999), 201.

33 Klaus Müller-Wille, "From World-Pictures to the Wild Architecture of the Book," in Asger Jorn: Restless Rebel, ed. Dorthe Aagesen and Helle Brøns (Copenhagen/ Munich: Statens Museum for Kunst, Prestel, 2014), 94 and note 6.

34 Ellef Prestsæter, "The Books of Asger Jorn and Rudolf Broby-Johansen," Report from the Gutenberg Galaxy (Blaker), no. 3 (2017): 54

35 As quoted in Prestsæter, 46; But, as Thomas Hvid Kromann notes, in spite of Jorn's admiration for Broby in certain respects, their relation became strained. Cf. "Broby vs. Jorn - billedernes og tekstens kamp om bogen," Bogvennen, 2019, 130-69 \& 185-88.

36 Asger Jorn, "Kunst og ordrer: Om forræderi, reproduktionens mængdevirkning og den store kunstneriske masseeffekt," Politiken, August 21, 1964, "Art and Orders: On Treason, the Mass Action of Reproduction and the Great Artistic Mass Effect," The Situationist Times, no. 5 (1964): 11; Cf. Prestsæter, "The Books of Asger Jorn and Rudolf Broby-Johansen," 46.

37 Rudolf Broby-Johansen, Sort Og Rødt: 64 Grafiske Glimt (Copenhagen: Gyldendal, 1982), 90-91. 
38 Benjamin H. D. Buchloh, "From Faktura to Factography," October 30 (1984): 118.

39 Jaleh Mansoor, Marshall Plan Modernism: Italian Postwar Abstraction and the Beginnings of Autonomia (Durham: Duke University Press, 2016).

40 The book was republished in 2001, cf. Asger Jorn, Pour la forme: ébauche d'une méthodologie des arts (1957; repr., Paris: Allia, 2001).

41 For an excellent analysis of the role of laundry soap (an omnipresent product that was critically remarked upon by, for instance, Lefebvre and Barthes) in relation to postwar France's twin dynamic of decolonization and modernization, see Ross, Fast Cars, Clean Bodies, chapter 2; For a theory of the labor saving device in relation to the omnipresent capitalist form of the "gimmick," see: Sianne Ngai, Theory of the Gimmick: Aesthetic Judgment and Capitalist Form (Cambridge, Massachusetts: The Belknap Press of Harvard University Press, 2020).

42 Guy Debord, The Society of the Spectacle, trans. Donald Nicholson-Smith (New York: Zone Books, 2006), 24.

43 Ibid., 12.

44 See Roland Simon, Fondements critiques d'une théorie de la révolution: au-delà de l'affirmation du prolétariat (Paris: Éd. Senonevero, 2001).

45 Jorn, "Dear Friends," 71.

46 Pia Jarvad, "Nye ord i dansk - fra 1955 til i dag," Dansk Sprognævn. Accessed on December 13, 2018, https:// dsn.dk/noid/?q=automation.

47 Debord, Correspondance. Vol. 1, 25; Guy Debord, Correspondence: The Foundation of the Situationist International (June 1957-August 1960), trans. Stuart Kendall and John McHale (Cambridge, Mass: Semiotext(e), MIT Press, 2009), 46.

48 Debord, Correspondance. Vol. 1, 25; Debord, Correspondence, 46; For a discussion of the role of myth in relation to the SI, see Fabien Danesi, Le mythe brisé de l'Internationale situationniste: l'aventure d'une avantgarde au coeur de la culture de masse (1945-2008) (Dijon: Les Presses du réel, 2008).

49 Letter from Guy Debord to Asger Jorn, September 1, 1957. BnF, Paris : Le Fonds Guy Debord.

50 Asger Jorn, "Les situationnistes et l'automation," in Pour la forme: ébauche d'une méthodologie des arts (1958; repr., Paris: Allia, 2001), 93-95.

51 Asger Jorn, "Les situationnistes et l'automation," internationale situationniste, no. 1 (June 1958): 22-25 Asger Jorn, "L'automation," Cahier pour un paysage à inventer, no. 1 (May 1960): 58-61; henceforth I quote from the English version available in: Asger Jorn, "The Situationists and Automation," in Situationist International Anthology, ed. and trans. Ken Knabb, revised and expanded edition (Berkeley, CA: Bureau of Public Secrets, 2006), 55-58.

52 Louis Salleron, L'automation, Que sais-je? (Paris: Presses universitaires de France, 1956).

53 Ibid., 7.

54 Ibid., 9.

55 Jorn, "The Situationists and Automation," 55

56 Ibid., 57. Emphasis added.
57 G. M. Birtwistle, Living Art: Asger Jorn's Comprehensive Theory of Art between Helhesten and Cobra, 1946-1949 (Utrecht: Reflex, 1986), 55.

58 Asger Jorn, Critique de la politique économique - Suivie de la Lutte Finale, Rapports présentés à l'Internationale situationniste, II (Paris: L'Internationale Situationniste, 1959), 5 . Jorn's contribution to Marxist critique of value theory, while it falls outside the scope of this thesis, remains to be properly assessed. An obstacle to this, however, is the generally poor translations into English that exist of this work. Admittedly, Jorn is perhaps not himself the most rigid Marxist thinker, and his argument tends to drift in the direction of an untenable vitalism of art, but the crucial distinction made here with regards to the concept of value in Marx anticipates developments in Marxist thought; A much more coherent and systematic argument advanced from the same basic premises is: Moishe Postone, Time, Labor, and Social Domination: A Reinterpretation of Marx's Critical Theory (New York, NY: Cambridge University Press, 1993).

59 Jorn, Critique de la politique économique - Suivie de la Lutte Finale, 29.

60 It is worth noting here, with Jorn-scholar Ruth Baumeister, an inversion on another level too, namely between Jorn and Debord in their respective roles as artist-impressario and master-theoretician. See Ruth Baumeister, "Introduction," in Fraternité Avant Tout: Asger Jorn's Writings on Art and Architecture, 19381958, ed. Ruth Baumeister (Rotterdam: 010 Publishers, 2011), 9.

61 Kromann, "Montages Wrapped in Flong," 2.

62 Ibid., 9.

63 Ibid., 3.

64 Ibid., 6.

65 Jorn, "Dear Friends," 71-72.

66 Hal Foster, The Return of the Real: The Avant-Garde at the End of the Century (Cambridge, Mass: MIT Press, 1996), 16.

67 For the best available analysis of the book's aesthetic features, see Karen Kurczynski, The Art and Politics of Asger Jorn: The Avant-Garde Won't Give Up (Burlington, VT: Ashgate, 2014).

68 Marshall McLuhan, The Mechanical Bride: Folklore of Industrial Man (1951; repr., London: Duckworth Overlook, 2011), 5.

69 McLuhan, 3.

70 Alberto Toscano and Jeff Kinkle, Cartographies of the Absolute (Winchester: Zero Books, 2015). 